\title{
Free-Living Wild Birds and Factors Influencing Their Survival in Captivity: A Synopsis
}

\author{
Ochuko Orakpoghenor $^{1 *}$, Sunday Blessing Oladele ${ }^{1}$, Paul Ayuba Abdu ${ }^{2}$ and Collins Chimezie Udechukwu ${ }^{2}$ \\ ${ }^{1}$ Department of Veterinary Pathology, Ahmadu Bello University, Zaria, Nigeria \\ ${ }^{2}$ Department of Veterinary Medicine, Ahmadu Bello University, Zaria, Nigeria
}

${ }^{\star}$ Corresponding author: Ochuko Orakpoghenor, Department of Veterinary Pathology, Ahmadu Bello University, Zaria, Nigeria; Tel: +2347067522037; E-mail: ochuko.orakpoghenor@gmail.com

Received: December 22, 2020; Accepted: December 28, 2020; Published: December 30, 2020

\begin{abstract}
Free-living wild birds are adapted to the natural unrestricted existence but their roles in the epidemiology of avian diseases and zoonosis have necessitated using them in experimental studies. Some of these free-living wild birds include Laughing doves, Speckled pigeons, Cattle egrets, Village weavers and African silver bills. The use of these birds in experimental studies therefore requires capture and transportation of the birds followed by creation of an artificial environment to mimic their natural habitat. This new created habitat no matter how conducive it seems to be would have impact on the survival of these birds ranging from psychological to physical. The outcome of these impacts on the other hand could be falsely interpreted to result from the experimental study and this could be misleading. Survival of several wild birds in captivity ranged from $4 \%$ for captive-bred birds to $41 \%$ for captured wild birds over a 2-month period with annual post-release survival of $89 \%$. Also, due to the survival mechanisms developed by wild birds in terms of feeding diversity, reproduction and disease tolerance in the wild, captivity would have effects on these instincts leading to lethal consequences. Hence in this article, some free-living wild birds and the factors affecting their survival in captivity, though not limited to these, are being discussed.
\end{abstract}

Keywords: Wild birds, Habitat, Impact, Captivity, Survival

\section{Introduction}

Free-living wild birds are birds with unrestricted migratory potentials and move independently. These birds have over time developed abilities to survive in their natural habitat which involves moving from one location to the other in search for food as well as suitable environment for reproduction. Due to their free-living nature, these wilds tend to play significant roles in the spread of diseases. This can be evident from studies where antigens of and antibodies against disease causing agents have been detected in some free-living wild birds. The mode of infection of these birds could only be speculated from their migration to locations where the infectious agents are present. Some of these infectious agents could cause clinical signs in other domestic animals but not in the free-living wild birds [1]; Fagbohun et al. [2-4]. The significant roles that these wild birds play in the epidemiology of diseases would only be better understood from using them in experimental studies, thus requiring putting them in captivity. Outcome of such experimental studies might be affected by alteration in the natural instincts of the birds and could lead to severe consequences. Hence, this article is focused on some free-living wild birds and factors influencing their survival in captivity.

\section{Some Free-Living Wild Birds}

\section{Laughing Dove}

The laughing dove (Spilopelia senegalensis) is a slim pigeon belonging to the order Columbiforme and family Columbidae [5]. It is distinguished from other doves by its call which sounds like human laughter [6], and a rufous and black chequered necklace gives it a distinctive pattern [5]. It is a resident breeder in Africa, the Middle East and the Indian Subcontinent [7]. This small long-tailed dove is found in dry scrub and semi-desert habitats [8].

The laughing dove is primarily an inhabitant of woodland and savanna, but is also found around human habitations, in farmland, villages and towns [5]. It feeds primarily on seeds, but it also eats other vegetable matter, such as fruit, as well as small insects, particularly termites $[8,9]$. The laughing dove typically occurs individually or in pairs but might also gather in flocks [10] at watering points, roosting spots, or in area of food abundance [11].

Laughing doves are mostly sedentary but some populations may however exhibit migratory potentials [5]. This is evidenced by recovery of the birds, originally ringed in Gujarat $200 \mathrm{~km}$ north in Pakistan and landing of exhausted birds on ships in the Arabian Sea [12]. Birds that landed on ships might have been introduced to new regions $[5,13]$.

\section{Speckled Pigeon}

The Speckled pigeon (Columba guinea) or (African) rock pigeon is a large pigeon belonging to the order columbiforme and family columbidae [14]. It has rufous on the back and wings with white spots heavily spotted on the wings. It is a resident breeder in most parts of Africa south of the Sahara [15]. 
The speckled pigeon lives mainly in open country, farmland, savannahs, grasslands, with nearby trees such as palms or baobabs [12]. It is also found in urban areas where it is often seen on roof tops [16]. It feeds mainly on seeds and cultivated grains [16]. It gathers in large numbers where grains or groundnuts are abundant. It is very gregarious and flocks may reach several hundreds of birds, mixed with other pigeon's species and doves [14]. It walks and runs easily on the ground. It has a strong and fast flight, and flies very high in the sky with regular wing beats [15]. Like laughing doves, the speckled pigeons are sedentary and may exhibit migratory potentials [15].

\section{Cattle Egret}

The cattle egret (Bulbucus ibis) is a cosmopolitan species of heron (family Ardeidae) found in the tropics, subtropics and warm temperate zone $[17,18]$. It is a white bird adorned with buff plumes in the breeding season [19] and is the only member of the monotypic genus Bubulcus [18]. It is originally native to parts of Asia, Africa and Europe [20], but has undergone a rapid expansion in its distribution due to wider human farming [18]. This bird maintains a special relationship with cattle where it removes ticks and flies from cattle and consumes them, thus implicated in the spread of tick-borne animal diseases [21].

The cattle egret feeds on insects, such as grasshoppers, crickets, flies (adults and maggots) [21], and moths, as well as spiders, frogs, and earthworms [22]. They usually nest in colonies and forage in fields with grazing livestock [20]. They are both sedentary and migratory [20], and migration is from cooler areas to warmer areas triggered by rainfall [19]. Due to their migratory potentials, cattle egrets have been implicated in the spread of poultry infections such as infectious bursal disease [3,23], Newcastle disease [24] and chicken infectious anaemia [4].

\section{Village Weaver}

Village weaver (Ploceus cucullatus), also known as the spottedbacked weaver or black-headed weaver, belongs to the order Passeriforme and family Ploceidae [25]. It is a species of bird widely distributed in the sub-Saharan Africa and occurs in a wide range of open or semi-open habitats, including woodlands and human habitation [26]. It frequently forms large noisy colonies in towns, villages and hotel grounds where it builds a large coarsely woven nest made of grass and leaf strips with a downward facing entrance suspended from a tree branch [27]. It has a strong conical bill, dark reddish eyes and yellow nape and crown [25].

Village weavers feed principally on seeds and grain, can be crop pests, and also readily feed on insects [27]. They have very strong migratory potentials with dearth of information on their role in the spread of diseases (Craig and de Juana 2017).

\section{African Silver Bill}

The African silver bill (Euodice cantans) belongs to the order Passeriformes and family Estriididae [28]. It is a common resident breeding bird in dry savanna habitat, south of the Sahara Desert but has also been introduced to other countries such as Portugal, Qatar and United States [29]. It has a long black pointed tail, stubby silver-blue bill, finely vermiculated light-brown upper parts, whitish underparts, black rump and black wings (BirdLife International 2012c). However, both sexes are similar and the immature birds lack the vermiculations. It is an inactive bird that stays in flocks all year round and usually breeds in loose colony [30].

The African silver bill feeds mainly on grass seeds [28] but has been reported to take aphids from water mint [31]. There is paucity of information on the migratory role of this bird in the spread of diseases but their presence around poultry houses is not uncommon [28].

\section{Influencing Factors on Survival of Free-living Wild Birds in Captivity}

\section{Stressors}

Stressors in captured wild birds could be in the form of capture, shipping/transportation, acclimatization and/or a new environment for birds already in captivity. These have the potential to reduce immunity, thus making the birds susceptible to new infections or could result in subclinical infections that may become life threatening [32-34]. In breeding and non-breeding house sparrows, trapping has been reported to initiate stress response [35].

\section{Diseases}

The introduction of new wild birds to a facility is posed with the risk of disease transmission [34,36]. Hence, the observation of all newly captured birds for clinical signs of disease, injury, or abnormal behavior must be carried out [33]. These include faecal examinations for intestinal parasites as well as visual examination for external parasites [36].

\section{Social Factors}

The studies of social behavior of group-living species may require housing of different bird species in groups in the same enclosure [37]. Due to the diversity of housing needs, mix species housing is unsuitable to avoid disease transmission between species [36]. Also, several species of wild birds may be routinely held in a single facility, provided that inter-species dominance over food or nervous responses of one species to another's calls does not result in additional stress [38]. However, mixed-species housing has been adopted in certain experimental conditions such as in the study of brood parasitism by viduine finches on estrildids, and a study of interspecific song acquisition [38].

\section{Feed}

There is greater diversity of feeds in the wild [39], hence, natural diet, including micronutrients, such as carotenoids involved in immune function should be considered for each species [40]. Wild birds in captivity require palatable, uncontaminated, and nutritionally balanced food daily or according to their particular requirements for survival [41]. However, feeding ad libitum could be problematic in species such as psittacines due to development of obesity resulting from the constant feed supply and the relative lack of activity in confinement [42]. Also, the reduction of total nutritional breadth has been associated with the consumption of minimal variety of seeds 
in seed eaters (Pruitt et al. 2008). Also, the unwillingness to feed on the floor has been reported in vigilant, predator-phobic birds newly placed in a large cage thus, requiring feeding on the floor or other location that enhances flight and increases energetic expenditure to maintain fitness [43].

It has been reported that feeding wild birds with varied diet early in life may enhance them to accept broad healthy diets as adults [4446].

\section{Lighting}

Since many species of birds see into the ultraviolet range $[47,48]$, their survival in captivity is dependent on the availabity of light [49]. These bird species use ultraviolet cues in various visual behaviors such as mate choice and foraging [50]. Also, full spectrum light has been reported to be beneficial in young birds in diseases such as rickets [51]. Therefore, in captivity, wild birds normally should be maintained on photoperiods natural to the species. Furthermore, behavioral problems such as aggression resulting from increasing hormone levels may also be managed by increasing the duration of the periods of darkness [50].

\section{Temperature}

The maintenance of a temperature range appropriate to the species is essential for their survivals in captivity [52]. However, daily temperature fluctuations should be minimized to avoid repeated large demands on the birds' metabolic and behavioral processes to compensate for changes in the thermal environment [52]. Extreme temperature changes may be stressful to the immune system or even lethal, and birds should be kept away from areas with appreciable fluctuations in temperature [53]. The time of year, ambient temperature and breeding activities have been reported to alter the optimal diet even within species [54].

\section{Space}

The concept of space is important for birds in captivity [55]. This allows for natural behaviors such as exercise, foraging, social interaction, relieves "boredom" and offset the development of abnormal repetitive behaviors [56].

\section{Conclusion}

Free-living wild birds are important source of companion to several individuals as well as being used for tourist attraction globally. Their ability to serve these purposes effectively is largely dependent on their welfare and survival in this new environment. These birds should be provided comfortable environment that mimics their natural habitat to ensure maximum survival. Hence, further studies on the optimum requirement for each species of wild bird in captivity should be conducted to promote ethical experimental studies involving them.

\section{References}

1. Diarmid Mc A (1955) Aspergillosis in free-living wild birds. Journal of Comparative Pathology 65: 246-249. [crossref]

2. Paixao Seva da A, Funada MR, Richtzenhain L, Guimaraes MB, de Oliveira Souza et al. (2011) Genotyping of Cryptosporidium spp. from free-living wild birds from Brazil. Veterinary Parasitology 175: 27-32. [crossref]
3. Orakpoghenor O, Oladele SB, Abdu PA (2020a) Research Note: Detection of infectious bursal disease virus antibodies in free-living wild birds in Zaria, Nigeria. Poultry Science 99: 1975-1977.

4. Orakpoghenor O, Oladele SB, Abdu PA (2020b) Chicken anaemia antibody status of laughing doves, speckled pigeons, Cattle egrets, Village weavers and African silver bills in Zaria, Nigeria. Journal of Veterinary Research Advances 2: 18-21.

5. BirdLife International. (2015a). "Spilopelia senegalensis". IUCN Red List of Threatened Species. Version 2015.4. International Union for Conservation of Nature.

6. Underhill LG, Underhill GD, Spottiswoode CN (1999) Primary moult and bodymass of the cape turtle dove Streptopelia capicola, and its abundance relative to the laughing dove S. senegalensis, in the Western Cape. Ostrich 70: 196-199.

7. Cheke, AS (2005) "Naming segregates from the Columba-Streptopelia pigeons following DNA studies on phylogeny." Bulletin of the British Ornithologists' Club 125: 293-295.

8. Adang KL, Ezealor AU, Abdu PA, Yoriyo KP (2008) Food habits of four sympatric columbids (Aves: Columbidae) in Zaria, Nigeria. Continental Journal of Biological Sciences 1: 1-9.

9. Satheesan SM, Prakash R, Datye H (1990) Biometrics and food of some doves of the genus Streptopelia. Journal of the Bombay Natural History Society 87: 452-453.

10. Siegfried WR, Underhill LG (1975) Flocking as an anti-predator strategy in doves. Animal Behaviour 23: 504-508.

11. Burton M, Burton R (2002) International Wildlife Encyclopaedia: Third Edition. Marshall Cavendish, New York.

12. Ali S, Ripley SD (1981) Handbook of the Birds of India and Pakistan. 3: 155-157.

13. Kumar PA (1977) Assisted migration of birds by ships. Journal of the Bombay Natural History Society 74: 531-533.

14. BirdLife International. (2017). Species factsheet: Columba guinea.

15. BirdLife International. (2012a). "Columba guinea”. IUCN Red List of Threatened Species. Version 2013.2. International Union for Conservation of Nature.

16. Harris E, de Crom EP, Labuschagne J, Wilson A (2016) Urban environment use by Speckled (Columba guinea) and Feral (Columba livia) pigeons on the University of South Africa's Muckleneuk campus. Applied Ecology and Environmental Research 14: 399-419.

17. Ojija F (2015) Ecology and influence of age and habitats on the diurnal activity patterns of Cattle egret (Bubulcus ibis). International Journal of Scientific and Technology Research 4: 107-111.

18. BirdLife International. (2015b). "Bubulcus ibis". IUCN Red List of Threatened Species. Version 2015.4. International Union for Conservation of Nature.

19. North American Bird Conservation Initiative (NABCI) (2016) The State of North America's Birds 2016. Environment and Climate Change Canada: Ottawa, Ontario.

20. Telfair RC (2006) Cattle egret (Bubulcus ibis). In: Poole, A. (ed). The Birds of North America Online. Cornell Lab of Ornithology, Ithaca, New York.

21. Seedikkoya K, Azeez PA, Shukkur EAA (2005) Cattle egret (Bubulcus ibis) habitat use and association with cattle. Forktail 21: 174-176.

22. Siegfried WR (1971) The food of the cattle egret. Journal of Applied Ecology 8: 447468 .

23. Fagbohun OA, Oluwayelu DO, Owoade AA, Olayemi FO (2000a) Serological survey of infectious bursal disease virus antibodies in Cattle egrets, pigeons and Nigerian laughing doves. African Journal of Biomedical Research 3: 191-192.

24. Fagbohun OA, Oluwayelu DO, Owoade AA, Olayemi FO (2000b) Survey for antibodies to Newcastle disease virus in Cattle egrets, pigeons and Nigerian laughing doves. African Journal of Biomedical Research 3: 193-194.

25. BirdLife International. (2012b). "Ploceus cucullatus". IUCN Red List of Threatened Species. Version 2013.2. International Union for Conservation of Nature.

26. Gill F, Donsker D (2017) Old World sparrows, snowfinches and weavers. World Bird List Version 7.1. International Ornithologists' Union.

27. Craig A, de Juana E (2017) Village weaver (Ploceus cucullatus). In: del Hoyo J, Elliott A, Sargatal J, Christie DA. and de Juana E. (eds.). Handbook of the Birds of the World Alive. Lynx Edicions, Barcelona. 
28. BirdLife International. (2012c). "Lonchura cantans". IUCN Red List of Threatened Species. International Union for Conservation of Nature.

29. Arnaiz-Villena A, Ruiz-del-Valle V, Gomez-Prieto P, Reguera R, C. Parga-Lozano, et al. (2009) Estrildinae Finches (Aves, Passeriformes) from Africa, South Asia and Australia: A molecular phylogeographic study. The Open Ornithology Journal 2: 29-36.

30. Baptista LF, Robin L, Eleanor V, Douglas AB (1999) Relationships of some mannikins and waxbills in the estrildidae. Journal für Ornithologie 140: 179-192.

31. Meinertzhagen R (1954) The education of young ospreys. International Journal of Avian Science 96: 153-155.

32. Macro I, Mentaberre G, Ponjoan A, Bota G, Manosa S, Lavin S (2006) Capture myopathy in little bustards after trapping and marking. Journal of Wild life Diseases 42: 889-891. [crossref]

33. Ferrell ST, Snowden K, Marlar AB, Garner M, Lung NP (2007) Fatal hemoprotozoal infections in multiple avian species in a zoological park. Journal of Zoo and Wildlife Medicine 28: 309-316. [crossref]

34. Laiolo P, Serrano D, Tella JL, Carrete M, Lopez G, et al. (2007) Distress calls reflect poxvirus infection in lesser short-toed lark (Calandrella rufescens). Behavioural Ecology 18: 507-512.

35. Lynn SE, Porter AJ (2008) Trapping initiates stress response in breeding and nonbreeding house sparrows (Passer domesticus): implications for using unmonitored traps in field studies. Journal of Avian Biology 39: 87-94.

36. Parmley EJ, Pearl DL, Vogt NA, Yates S, Campbell GD, et al. (2015) Factors influencing mortality in a captive breeding population of Loggerhead Shrike, Eastern subspecies (Lanius ludovicianus ssp) in Canada. Biomedical Central Veterinary Research 11: 1-7.

37. Lange H, Leimar O (2004) Social stability and daily body mass gain in great tits. Behavioural Ecology 15: 549-554.

38. Hahn BA, Silverman ED (2007) Managing breeding forest songbirds with nonspecific song playbacks. Animal Conservation 10: 436-441.

39. Koutsos EA, Matson KD, Klasing KC (2001) Nutrition of birds in the order Psittaciformes: A review. Journal Avian Medicine 15: 257-275.

40. Blount JD, Metcalfe NB, Birkhead TR, Surai PF (2003) Carotenoid modulation of immune function and sexual attractiveness in zebra finches. Science 300: 125-127. [crossref]

41. Barrett LF, Mesquita B, Ochsner KN, Gross JJ (2007) The experience of emotion. Annual Review of Psychology 58: 373-403.

42. Pruitt KD, Hewitt DG, Silvy NJ, Benn S (2008) Importance of native seeds in whitewinged dove diets dominated by agricultural grains. Journal of Wildlife Management 72: $433-439$.
43. Schnegg A, Gebhardt-Heinrich SG, Keller P, Visser H, Steiger A (2007) Feeding behaviour and daily energy expenditure of domesticated budgerigars (Melopsittacus undulatus): Influence of type of housing and vertical position of the feeder. Applied Animal Behavior Science 108: 302-312.

44. Liukkonen-Anttila T, Putaala A, Hissa R (1999) Does shifting from a commercial to a natural diet affect the nutritional status of hand-reared grey partridges Perdix perdix? Wildlife Biology 5: 147-156.

45. Van Heezik Y, Lei P, Maloney R, Sancha E (2005) Captive breeding for reintroduction: Influence of management practices and biological factors on survival of captive kaki (black stilt). Zoo Biology 24: 459-474.

46. Moore SJ, Battley PF (2006) Differences in the digestive organ morphology of captive and wild Brown Teal (Anas chlorotis) and implications for releases. Bird Conservation International 16: 253-264.

47. Cuthill IC, Partridge BC (2000). Ultraviolet vision in birds. Advances in the Study of Behavior 29: 59-190.

48. Rajchard J (2009) Ultraviolet (UV) light perception by birds: a review. Veterinarn Medicina 8: 351-359.

49. Lustick S (1973) The effect of intense light on bird behavior and physiology. Bird Control Seminar Proceedings 6: 171-186.

50. Maddocks SA, Cuthill IC, Goldsmith AR, Sherwin CM (2001) Behavioural and physiological effects of absence of ultraviolet wavelengths for domestic chicks. Animal Behaviour 62: 1013-1019.

51. Edwards HM, Elliot MA, Sooncharernying S, Britton WM (1994) Quantitative requirement for cholecalciferol in the absence of ultraviolet-light. Poultry Science 73: 288-294. [crossref]

52. Ardia DR, Perez JH, Chad EK, Voss MA, Clotfelter ED (2009) Temperature and life history: experimental heating leads female tree swallows to modulate egg temperature and incubation behavior. Journal of Animal Ecology 78: 4-13. [crossref]

53. Laurila M, Hohtola E (2005) The effect of ambient temperature and simulated predation risk on fasting-induced nocturnal hypothermia of pigeons in outdoor conditions. Journal of Thermal Biology 30: 392-399.

54. Harper EJ (2000) Estimating the energy needs of pet birds. Journal of Avian Medicine and Surgery 14: 95-102.

55. Dawkins MS (2006) A user's guide to animal welfare science. Trends in Ecology and Evolution 21: 77-82. [crossref]

56. Meehan CL, Millam JR, Mench JA (2003) Foraging opportunity and increased physical complexity both prevent and reduce psychogenic feather plucking by young Amazon Parrots. Applied Animal Behaviour Science 80: 71-85.

\section{Citation:}

Orakpoghenor O, Sunday Blessing Oladele, Paul Ayuba Abdu, Collins Chimezie Udechukwu (2020) Free-Living Wild Birds and Factors Influencing Their Survival in Captivity: A Synopsis. Integr J Vet Biosci Volume 4(3): 1-4. 